This is an Accepted Manuscript of an article published by Taylor \& Francis in Public Management Review on $2^{\text {nd }}$ October 2017, available online:

http://www.tandfonline.com/doi/full/10.1080/14719037.2017.1383718

Article title:

THE CHALLENGES OF POLICE-COMMUNITY COLLABORATION:

IDENTITY MANOEUVRES AND POWER STRUGGLES IN A

NEIGHBOURHOOD BASED MEETING

Journal title:

Public Management Review

Authors:

Anita Mangan*

Keele Management School

Keele University

Staffordshire ST5 5BG

UK

a.m.l.mangan@keele.ac.uk

Robyn Thomas 
Cardiff Business School

Cardiff University

Cardiff CF10 3EU

UK

thomasr4@cf.ac.uk

Annette Davies

Cardiff Business School

Cardiff University

Cardiff CF10 3EU

UK

daviesa4@cf.ac.uk

Roz Gasper

University of the West of England

Bristol BS16 1QY

UK

roz.gasper@uwe.ac.uk

*Corresponding author 


\title{
THE CHALLENGES OF POLICE-COMMUNITY COLLABORATION: IDENTITY MANOEUVRES AND POWER STRUGGLES IN A NEIGHBOURHOOD BASED MEETING
}

\begin{abstract}
The turn to collaborative governance is a key feature of the New Public Governance environment in many Western economies. Within the UK, successive governments have mandated policing organisations to engage in public service partnerships and collaborate with communities. This paper examines one such collaborative arrangement, namely, neighbourhood public meetings. Drawing on a theoretical framing of the dynamic relationship between identities, agency and power, we critically explore how individuals seek to persuade, defend and legitimate their values, beliefs and practices in collaborative situations. The paper provides a nuanced exploration of the challenges of collaboration for both public servants and community members.
\end{abstract}

\section{Key words}

Citizen participation, collaboration, discourse, identity, police 


\section{INTRODUCTION}

Over three decades, public service organisations and professionals in many Western economies have been the target for significant changes. These reforms have presented challenges to the management and delivery of public services. The introduction of performance targets and market-oriented cultures, together with increasing levels of government intervention have presented considerable challenges for public service professionals' ability to deliver effective services (Baxter 2011). In view of diminishing levels of public confidence, reforms have focused increasingly on the involvement the public in decision-making and on a greater 'personalisation' of public services (Martin 2011) as part of the New Public Governance (NPG) of a plural, pluralist, networked state (Osborne 2006). Policing organisations in the UK have a long, chequered history of engaging with other public servants and with their communities in service delivery (Crawford 2007; Gasper and Davies 2016). In particular, professional-community engagement has proven to be extremely challenging while managing demanding and contradictory performance targets, and attempting to resolve differing interests and goals that arise in collaborative working (Skelcher and Sullivan 2008; Jones and Ormston 2014).

This paper focuses on the challenges confronting policing professionals in collaborative public meetings involving the police, other public service partners and the public. Data is drawn from observations of situated social interactions that unfold in one meeting, itself part of a two-year ethnography on 'Partnerships and Communities Together' (PACT) meetings, which were introduced in the UK as a key element of the Neighbourhood Policing (NP) programme. Our analysis highlights the context within which the meeting participants are located, and the tensions and the awkward decisions that the police face within this collaborative content. 
We draw on conceptual insights that explore the dynamic relationship between identities, agency and discourse. Identity has been a strong theme within research on public service organizations in recent years, where public sector reform has been characterised as an 'identity project', targeting professional values, discretion and purpose (du Gay 1996; Meyer and Hammerschmid 2006; Thomas and Davies 2005). Our analysis addresses the call for a greater focus on how collaboration works, as it happens and unfolds (Martin 2012; Bevir and Trentmann 2007), so as to offer a more nuanced account of the experiences of individuals and groups involved in collaborations (Dickinson and Sullivan 2014).

The paper offers three main contributions. Firstly, taking a relational identities approach (Creed, DeJordy, and Lok 2010), we critically explore the role of discourse, identity and agency in collaborative working, gaining greater insight into the complex relations and micro-political identity manoeuvres that underpin collaborative practice. Secondly, the paper provides a more nuanced appreciation of the demands and constraints faced by front line public service employees. Finally, our theoretical framing contributes to an understanding of the wider context on collaboration, linking the micro-political manoeuvres with the political arena in which collaborative forums operate.

In the following sections, we examine the 'turn to' collaboration in organisational practice as a key element of NPG. We discuss existing research on identities in collaboration, and our theoretical framing. Following an account of the methods, we turn to the PACT meeting, which is the focus of our analysis. We outline the contributions that our study offers for a more nuanced appreciation of collaborative practice and the challenges confronting public service professionals and the communities they serve. 


\section{COLLABORATION AND PUBLIC SERVICE REFORM}

Collaboration has become a buzzword in public service reform and modernisation in many countries over the past three decades (Dickinson and Sullivan 2014). Forming the lynchpin of New Public Governance (NPG) (Osborne 2006), where 'multiple different actors contribute to the delivery of public services and the policymaking system' (Dickinson 2016, 42), Agranoff and McGuire (2003, 4) describe collaborative working as:

the process of facilitating and operating in multi-organizational arrangements to solve problems that cannot be solved or solved easily by single organizations. Collaborative means to co-labour, to achieve common goals, often working across boundaries and in multi-sector and multi-actor relationships.

Collaborative arrangements may be distinguished from other forms of joint working, such as cooperation and coordination, with the former being seen as a more informal and short term pooling of resources, while the latter may be understood as a longer term marshalling of organizational units towards a particular goal.

Collaboration involves a closer set of relationships and is marked by the emergence of new structures and forms of shared working (Poocharoen and Ting 2015). As such, collaboration can be viewed as an overarching concept (Poocharoen and Ting 2015), covering a range of different institutional arrangements, including inter-organizational networks (Klijn and Koppenjan 2016) co-production (Alford 2002; Bovaird 2007) and forms of citizen participation (Arnstein 1969; Newman et al. 2004), such as deliberative forums (Newman et al. 2004). It is this latter form that is the focus of this 
paper, a form of ‘responsible and active citizenship' (Newman et al. 2004, 205) with not only 'project politics', i.e. involving citizens to agree upon and address specific local problems, but also the 'politics of presence', i.e. giving voice to citizens in the deliberative process (Bang 2002, cited in Newman et al. 2004, 204).

The move from 'provider centric models' (Bovaird 2007, 844) or representative democracy, to deliberative forms (Newman et al. 2004), embracing the user and communities, is seen to be efficacious in tackling complex social issues such as poverty, regeneration and crime and disorder in multicultural contexts (Gilling 2007; Ling 2002; Andrews and Entwistle 2010). Community and citizen collaboration is thus seen as facilitating synergistic, innovative solutions to complex problems and to effective utilisation of resources (Hardy, Lawrence, and Grant 2005). However, alongside talk of such potential 'collaborative advantage' (Huxham 2000; Huxham and Vangen 2005), research also points to the difficulties in developing effective collaborations (Sullivan, Williams, and Jeffares 2012; Vangen, Hayes, and Cornforth 2015). Huxham and Vangen $(2004,191)$ note the frequently encountered problem of 'collaborative inertia'; collaborative working is often highly resource intensive, with any collaborative advantages being overshadowed by the effort - the 'pain and grind' as one of the respondents in Huxham and Vangen's $(2004,200)$ study put it involved in working this way. In particular, with community forms of engagement, collaborations are often sites of contestation and struggle between different agencies, community groups and agendas (Hughes 2007; Hodgson 2004). Collaboration often involves interactions with individuals from different backgrounds and organisations, often facing multiple forms of governance, and accountable for targets, agendas and standards that can be conflicting and incompatible. Moreover, the communities 
involved are often fragmented, consisting of disparate and unequal groups (Brent 2004, Utting 2009).

The struggle involved in balancing conflicting demands highlights the power relations underpinning collaboration. Power often remains vested in the hierarchical public agency, with a reluctance to release power to community or citizens (Vangen, Hayes, and Cornforth 2015). In many instances, certain actors are better positioned than others to pursue their own agendas (Huxham 2003; Huxham and Vangen 2005; Tomlinson 2005). This means that genuine collaborations are extremely rare, where power relations are balanced and where there is a co-construction of meanings by a variety of actors. As Arnstein's (1969) eight stage 'ladder of participation' notes, collaborations can function quite cynically, being little more than 'manipulation' or 'therapy'. Further up the 'ladder', more promising but still rather etiolated versions can be noted, such as 'informing', 'consultation', and 'placation', before reaching more genuine forms of 'partnership', 'delegated power' and 'full citizen control', where citizens have full power over decision making.

The approach in this paper draws on Rhodes' $(2007,1251)$ 'decentred analysis' to argue that to understand how collaborative arrangements work, we need to unpack the underlying belief systems and daily practices of the individuals involved. This calls for an approach that focuses on situated social interactions within collaborative arrangements to understand better the role of discourse, identities and agency in the practice of collaboration. Specifically, the paper focuses the constructing and managing of multiple meanings and identities within collaborative arrangements involving the UK police. For the UK police, collaborative community engagement is viewed as a mechanism to tackle crime prevention and provide reassurance (Newburn and Reiner 2007), culminating in the introduction of 
neighbourhood policing. PACT meetings are offered as a deliberative forum where the police, community members and other public service partners engage in the collaborative governance of crime and disorder.

The introduction of PACT meetings must be appreciated against a backdrop of historical levels of distrust between the police and some communities (Huey and Quirouette 2010). Police and community residents often have divergent interests, with the police facing conflict over their priorities, based on intelligence and problemsolving policing, compared with those issues raised by residents (Herbert 2006). Moreover, and not surprisingly, power relations are asymmetrical, with the police tending to have a greater ability to influence agendas and procedures (Skogan 2006; Terpestra 2009). Thus, it may be impossible to develop the higher quality forms of participation within alienated and deprived communities (Liederbach et al. 2007), where interactions often involve heightened emotions (Komporozos-Athanasiou and Thompson 2015).

How policing professionals handle such challenges is the central focus of this paper. Collaborative working brings to the fore struggles over meanings and identities both between and within individual actors (Newman et al. 2004), presenting a complex dynamic of mutual constitution between self, organization and community, and involving the crossing of social, linguistic and ideological boundaries, where distinctions between self and other are likely to be heightened and problematized (Beech and Huxham 2003). Crucially, collaborative working requires individuals to draw on understandings of self, occupational and organizational identities, as well as other identity categories of both self and others, to act collectively (Maguire and Hardy 2005). In the police, partnership working has been seen to be antithetical to core policing identities and meanings around 'real policing' (Davies and Thomas 
2008). Greater understanding and appreciation of police officers' agency (Dickinson and Sullivan 2014), the meanings they give to collaboration, and the processes of identity work as part of these complex boundary dynamics, is essential in engendering effective collaborations. The paper thus highlights the importance of understanding the interactions of identities and agency in collaboration, to consider how 'collaboration is shaped and constrained by social values and by an individual agent's attachment to them and/or interpretation of them' (Dickinson and Sullivan 2014, 172). The following section sets out our theoretical approach to understanding identities and agency in collaboration.

\section{RELATIONAL IDENTITIES AND AGENCY}

While there is a range of different approaches to conceptualising identity, recent interest has eschewed essentialist understanding, as something that is a fixed given. Rather, identity is viewed as a constructed, dynamic and reflexively ordered narrative (Giddens 1991; Thomas 2009). Of particular interest in the study of individuals in organizations is the concept of 'identity work', defined as 'the mutually constitutive processes whereby people strive to shape a relatively coherent and distinctive notion of personal self-identity and ... influence the various socialidentities which pertain to them in the various milieu in which they live their lives' (Watson 2008, 129). Identity is viewed as an 'ongoing accomplishment' (Creed et al. 2010, 1341) by the individual in response to the related questions of: "Who am I?" and - by implication - "how should I act?"” (Alvesson, Ashcraft, and Thomas 2008, $6)$. 
Crucial to identity work, therefore, is the question of agency. Giddens (1976, 75) defines agency as 'the stream of actual or contemplated causal interventions of corporeal beings in the ongoing process of events-in-the-world.' Identity work is embedded and relational and is conducted in respect of and response to other actors (Creed et al., 2010; Watson 2008). It involves an on-going process of relational manoeuvring that comprises taking on, resisting, rejecting and reformulating understandings of self and other in order to gain status and legitimacy (Brown 2015; Ybema, Thomas, and Hardy 2016). Such manoeuvring can be particularly skilled, demonstrating great adaptability over self-positioning and in reading the prevailing context (Halford and Leonard 2006; Brown 2015).

An individual's sense of self is achieved through drawing on prevailing discursive resources, i.e., cultural scripts and normative prescriptions, as well as their own self-narrative, which is in turn, shaped by personal values, ideologies and political preferences. This is achieved through the 'positioning' (Davies and Harré 1990) of the self within a discourse, which offers a limited number of subject positions (Davies and Harre 1990) and therefore, the ability to have 'voice' and to formulate a legitimate identity functions in a dynamic relationship with prevailing discourses. By focusing on the dialogical interactions of self-other talk (Ybema et al. 2016) within the PACT meeting, we are able to reveal the mechanics of police agency. The collaborative arrangements of the meeting are situated within multiple, conflicting and complex discourses that come together to construct the collaborative arrangements. Following Foucault (1990), we understand discourse to be collections of interrelated texts and practices that 'systematically form the object of which they speak' (Foucault 1972, 49). Discourses thus rule in certain ways of thinking and being, while ruling out others: [discourse] 'governs the way that a topic can be 
meaningfully talked about and reasoned about. It also influences how ideas are put into practice and used to regulate the conduct of others' (Hall 2001, 72). Thus, discourses may be used tactically by individuals to achieve a particular goal. Analysing how social interactions are informed by and shape identities within collaborative meetings can help to reveal the effective working of collaborative arrangements (Dickinson and Sullivan 2014). Accordingly, we explore how the interactional dynamics and the wider discursive setting work in collaborative arenas to reveal the challenges of these environments for public service professionals and for the communities they serve.

\section{METHODOLOGY}

Our paper draws on material from a two-year longitudinal ethnography of the experiences of PACT within different communities in Wales.

\section{Research design}

The empirical setting is within one police constabulary ${ }^{1}$ located in Aberderi (pseudonym), South Wales. The authors attended, together and separately, more than 50 meetings, conducting interviews with over 40 police officers, 12 service partners, and 8 councillors. In addition, three focus groups with PACT resident attendees were held. This study of PACT provides us with greater insights into the context, discourses of change, as well as the macro professional and socio-political discourses that inform textual meanings and identities constructed within these meetings. The empirical material for this paper mainly focuses on the interactions between residents, police, and public service partners within one meeting. 
The decision to focus on one meeting was driven by practical as well as theoretical choices. This situated analysis of the micro-practice of collaboration enabled a more nuanced appreciation of the challenges and difficulties faced by police officers and of the way these are informed by the construction of different meanings and identities. The meeting selected also had a 'critical emotional incident' where a local resident disrupted the meeting's regular routine to such an extent that the meeting threatened to end in chaos. Discussing the events, we agreed that we had witnessed an important rupture in the official discourse of Neighbourhood Policing (NP), with its focus on citizen engagement and reassurance policing. The manner in which the meeting had been 'saved' alerted us to a complex set of competing discursive resources that police officers drew on in order to address challenges and regain control in exercising their agency, suggesting that public sector employees might be required to engage in complex identity manoeuvres in changed work environments.

\section{Data collection}

The PACT meeting was attended by three of the paper's authors. Two authors took verbatim notes of the talk, while the third noted interactions, emotions and general observations. One author took the lead in transcribing the meeting, with others contributing afterwards. The transcript was discussed to uncover any areas of disagreement or contradiction in the text or events. We also compiled individual reflections, including key points, their meanings, and how we constructed the individual, occupational and group identities.

\section{Data analysis}


Our initial analysis involved exploring salient discourses within the PACT based on our detailed transcripts and interpretations of this meeting, our wider research on PACT meetings, interviews with key personnel, and our knowledge of relevant literatures. We conducted a detailed real-time analysis of the discourses circulating in the meeting and the associated subject positions. Specifically, we were concerned to avoid reductive accounts that equate normative behaviour and discursive practices to pure narrative, thus losing the focus on the circulation of power and material practices (Hook 2001). Accordingly, we looked for areas of problematisation (McMurray, Pullen, and Rhodes 2011), where individuals had a choice between multiple competing discourses. We were also interested in the exclusions and limitations on discourse and on the way that some discourses may have limited power effects. Thus, we were not only concerned with what was said in the meeting, and with who can speak authoritatively, but also in what cannot be said, namely 'what is impossible or unreasonable within certain discursive locations' (Hook 2001, 527).

In mapping the circulating discourses, we each, individually examined the transcript of the meeting to note down what we saw as the salient discourses, drawing from our knowledge of the wider project and previous research. We then compared our individual analysis to arrive at an agreed list of five dominant discourses: professional policing; community; law and order; governance by partnership; and public service. For each of these discourses we noted several 'discursive strands' that emphasised contrasting meanings of the discourse (see Table 1).

- insert Table 1 about here -

We then returned to the transcript of the meeting and, comparing our individual analysis, noted three distinct phases distinguishable by the different 
interactions between the participants. These were: phase 1, the early part of the meeting, marked by police in control and promoting NP interests; phase 2, the middle section of the meeting, where there was much more confrontation and clashing of interests; and phase 3, towards the end of the meeting, marked by a move towards shared interests and expressions of 'fair play'. For each of these phases, we worked through the text of the interactions of the meeting members in chronological order, noting first who made the interaction, secondly how this interaction expressed choices, thirdly, the discourses invoked, and finally, the subject positions evident (see Table 2 for a list of the salient discourses and associated subject positions). We then noted different episodes of police/community interaction; how interactions expressed decisions and presented challenges for the police; the discourses invoked; and identities and meanings that were evident. We thus developed an 'interpretive interactions analysis' (Al-Amoudi and Willmott 2011) showing how people responded to the interactions of others, made claims to knowledge and identities, spoke authoritatively on issues, or were denied a voice.

Finally, we explored the verbal and non-verbal elements of the PACT meeting and context that were noted during our observations. Again, we discussed our individual notes as a research team, to arrive at a shared set of meanings. Verbal practices included, for example, tactical statements used to persuade others and create consensus. Non-verbal elements included immediate aspects such as the meeting room layout, individuals' appearance, and the wider setting of Aberderi, details of which are set out in the following section.

\section{The Aberderi PACT setting}


Aberderi is a small former coal mining community, located in the South Wales valleys. It has severe social problems, including high rates of unemployment, poverty, addiction, crime and violence. Aberderi is a relatively static community; people have spent their entire lives in the area. People know each other, including the 'trouble makers', the police and councillors, who often also come from the same community.

The setting for the 90-minute meeting was a rundown former public library. This PACT meeting had been running for nearly a year and participants were well versed in the format and meeting routines. Like other PACT meetings, this one was comprised of three demarcated groups: police, public and other public service agencies. Police representatives were the neighbourhood police officer, police constable (PC) Joe, and two police community support officers (PCSOs), Tom and Gareth. These officers are positioned within the formal Neighbourhood Policing discourse as 'servants of the community'. All three police representatives had a high level of local knowledge and were well known in the community. PC Joe had worked in Aberderi for the past decade and he described himself and the two PCSOs as "stereotypical "bobbies on the beat"' 2 . PC Joe was open about the difficulties he faced in these meetings, wryly observing: 'Yeah, that's right...come and throw sponges at the policeman in the stocks!' The PCSOs both came from Aberderi and shared the same accent and detailed knowledge of the area with the community. Attending the meeting, the three police officers were all in uniform and sat formally at a desk in the front of the meeting room.

There were approximately 30 residents present, slightly more women than men and mostly over 50. Most were dressed casually, had local accents and knew each other well. Echoing the existing research on PACT attendance (Bullock 2010; Brunger 2011; Sagar and Jones 2013), the extent to which resident attendees are 
representative of the community was a concern for PC Joe who argued that the Aberderi PACT comprised of the 'usual suspects': the retired and community volunteers. Younger community members were noticeably absent. One attendee was from a minority ethnic group (although Aberderi has a very small black and minority ethnic population).

The public service partners' presence is part of the PACT vision, signifying a shift toward a collaborative approach to wider service delivery across the public services (Flanagan 2008). In practice, their attendance is patchy and tends to occur only when the police specifically requested their presence. Representing the public service partners at this meeting were three local councillors, Councillors Jones, Davies and Williams, and two detached youth workers, Joanne and Kirsty. These individuals were dotted around the room, indistinguishable in appearance from the local residents. Their roles only became apparent when PC Joe introduced the police and public servants at the start of the meeting.

\section{Discourses circulating in the PACT meeting}

From our analysis of the meeting, we identified five dominant discourses circulating in the meeting: professional policing; community; law and order; governance by partnership; and public service. For each of these discourses we noted a number of 'discursive strands' that emphasised contrasting meanings of the discourse (see Table 2). By examining the evidence and circulation of these discourses in the meeting, and their interplay with individual constructions of identity, we are able to plot the micropolitics of collaborative practice.

- $\quad$ insert Table 2 about here - 
The professional policing discourse comprises overlapping, competing, and contested discursive strands. Firstly, a 'hard reactive' style of authoritarian policing, with a subject position of the 'authoritarian crime fighter' often identified with 'real police work' and focusing on public order (Innes 2005). Secondly, a neighbourhood policing strand, part of a broader citizen-focused public service discourse in the UK and emphasising non-coercive policing, community interaction, problem solving, communication and ensuring community consent for police actions (Somerville 2009; Innes 2005), with the associated subject position of 'accountable partner'.

The community discourse has two competing discursive strands. First, the ideal of the homogeneous, shared and responsible community (Young 2003), found in the appeals to 'the community' and 'community engagement' that underpin many public service initiatives (Brent 2004; Newman and Clarke 2009). In sharp contrast is a discursive strand that is highly sceptical of the possibility of community cohesion, with community membership seen as pluralistic social relationships (Hughes 2007; Crawford 2007) and communities as places of difference and transience. Within this more stratified discourse, some residents may be considered 'lesser citizens' (Utting 2009) and 'anti-social', in contrast to the 'good neighbours and citizens' who attend PACT meetings.

A third discourse is that of law and order, with discursive strands aligned with the authoritarian and consensual policing discourses already discussed. The first conveys intolerance to any type of criminal or anti-social behaviour, demanding aggressive and authoritarian policing interventions to carry out 'zero tolerance' measures. The alternative law and order discursive strand lies within a tolerant and balanced approach, more closely aligned to the neighbourhood policing discourse. Here, effective law and order and crime control is acknowledged as a complex and 
long term process, where constant enforcement may be neither possible nor desirable (Newburn and Jones 2007). The focus and emphasis is on professional discretion and on the broader socio-economic conditions that contribute to such behaviours.

The fourth discourse we note in our analysis of the meeting is that of partnership. There are three distinct strands. The citizen as participant discursive strand privileges citizens and service users working collectively with professionals in shaping public service priorities and solutions. 'Strategic' partnership emphasises the collaboration of elite decision-makers in different public service agencies to delivering ‘joined-up’ service delivery. Finally a managerialist discursive strand reduces the emphasis or potential of partnership, identifying the tensions and dilemmas between different agencies (Newman and Clarke 2009) and the power of professional expert elites (Clarke et al. 2007).

The final discourse relates more broadly to the notion of public service and the role of public service professionals in meeting society's needs. The first strand aligns with producing strategic, innovative solutions to societal problems, thus promoting an 'empowered' public service discourse and an associated subject position of the innovative problem solver. Here gains are achieved through joined-up working involving a broad range of stakeholders who have the ability 'to make a difference' (Newman and Clarke 2009). The other complementary strand constructs a more constrained public service discourse. This acknowledges the tight performance management regimes within different public agencies and the challenges posed for service delivery within the context of reduced public service funding.

It is through these discourses that individuals formulate their identities and from which they are able to speak as legitimate subjects within the meeting. In the following section, we focus on three specific interactions in the meeting, tracing 
police officers' mobilising of the above discourses, and the subject positions taken on by the police in their interactions with other meeting participants. While the focus here is on how the police mobilise certain discourses and subject positions, we recognise that the identity work of community members is also an equally important feature of collaborative work in practice. However, detailed analysis of other meeting participants is beyond the scope of this paper.

\section{COLLABORATIVE WORKING IN PRACTICE}

The following extended analysis of the Aberderi PACT focuses on three distinct sets of interactions to illustrate the dynamics of discourse, identity and agency in the police members' responses to the challenges of collaborative working.

\section{Police control of the PACT meeting and the promotion of NP}

PACT meetings were introduced as a top-down initiative mandated by police performance targets. Therefore, despite the 'P' of PACT representing 'partnerships', these meetings are considered by other public service partners and by many residents to be 'police owned'. Routinely, the police officer and PCSOs sat at a top table, and attempted to control the collaborative event. This control was evident from the outset with the formal introduction by PC Joe (meeting chair), who read from his PACT script. This activity gave him an opportunity to establish an agenda wherein categories of interpretations, permitted talk and subject positions were set. Hence, PC Joe positioned himself within the neighbourhood and visible policing discourse as an accountable partner and the archetypal 'bobby on the beat', providing a service and 
ensuring residents' satisfaction. He spoke from this subject position repeatedly, to control the meeting according to his agenda and promote Neighbourhood Policing:

So, the priorities that we set last month were, um, youth annoyance in Aberderi park, especially around The Community Hut; youth annoyance and damage to cars in Manor Street and parking along Treherbert Street. We've now been running these meetings for the past 8 or 9 months and I'd like to thank you all for your help and regular attendance. You are the eyes and ears of the community. So, let's kick off with the problems we're been having with youngsters around the Community Hut. We've had officers patrolling the area but no offences have been reported (PC Joe).

Noticeable in this extract are the number of discursive manoeuvres that PC Joe undertakes to display his intentions, set boundaries, expectations, emotional tone, agenda and direction of talk in the meeting. PC Joe draws on the PACT meeting's dispositional arrangements to exercise control over the meeting's members. These include the use of non-verbal practices such as the hierarchical seating arrangements (the police sit at a 'top table' and in uniform), as well as a series of verbal tactics whereby PC Joe looks for, and receives, confirmation from the audience: 'Can I ask if there's been any improvement?' There is a procedural feeling to PC Joe's manner and if the meeting veers off his agenda, he brings the topic back to the agreed priorities, again asking the meeting to confirm his position as in control: 'Going back to last month's priorities, are we happy with that?' He gains further support and confirmation from the meeting members when he brackets off unrealistic expectations: 'can't promise everything but we will try our best'. Within these interactions, we see how PC Joe, in positioning himself as 'an accountable partner' in 
the NP discourse, controls who can speak authoritatively, attempting to delineate who can criticise the police and on what they can be criticised.

PC Joe's constant attempts to exercise control and promote NP show how challenging these interactions can be and often feelings of exasperation emerged. He persistently promotes and defends the NP subject position within the discourse of partnership governance, by promoting the collective 'we' of the police and community members working together: 'we can't solve society's problems. PACT meetings are a chance for us to focus our resources where we can'. He repeatedly positions himself within the service and community-oriented NP discourse: ' $I$ am accountable to this community' and as a disempowered police officer within a discourse of a highly constrained public service: 'We're doing all we can do-we're only human and there is limited resource'.

\section{The residents' challenges: Anger and tensions in PACT meetings}

In many of the meetings observed, especially those in the most deprived communities, residents would often talk of unmet needs and their low level of trust in the police and other service providers. The emotional tone was often angry, with residents feeling let down by 'soft policing'. In this meeting, we can see how PC Joe struggles to maintain his polished ideal-type NP officer performance. We see noticeable changes in the nature and tone of these interactions as the meeting becomes more conflicted, emotional and tension-charged. The discussion in these interactions is focused on youth crime and antisocial behaviour, with increased demands by community residents, who challenge PC Joe, rejecting his promotion of an NP discourse. In particular, they raise a number of complaints relating to quality of life issues ('We don't want the elderly terrorised'; 'It is as bad as it ever has been') and 
voice their dissatisfaction with the police service's response to these problems ('We just want the police to be seen to be taking action'). This represented a different NP subject position that developed robustly in the residents' talk, located within a 'zerotolerance' discourse of law and order, demanding a more authoritarian police response. These resident attendees position themselves as 'law-abiding citizens' within the stratified community discourse differentiating the 'other' as the anti-social members of the community:

Resident 6: They're doing as they please. It's as simple as that.

Resident 3: I've heard terrible things... old people being intimidated in Cwm - petrol being poured through doors.

Resident 1: We need zero tolerance. If the Mayor of New York, Mayor Giuliani can clear up New York, what's wrong with doing it in Aberderi?

Here, residents are explicitly critical of the police and actively contradict the NP discourse. In this next extract, PC Joe's identity becomes a focus of attack, with demands for him to 'toughen up!'. In challenging the identity manoeuvres of PC Joe (the police as accountable partner), what emerges is a clash between citizens who locate themselves within a zero-tolerance law and order discourse and an authoritarian policing subject position, and the NP subject position that is invoked by PC Joe and which he tries to defend. A clearly demarcated 'them and us' division develops:

Resident 6: I phone time and time again to the police and they don't turn up ... Sorry, I'm very irate! 
PC Joe: I'm put here to answer questions over things I'm not paid to do. If you have a complaint about the police, make it! This is a problem with society and I can't solve society's problems.

Resident 6: [sounding very angry] We just want the police to be seen to be taking action.

PC Joe: If you've got a problem, then make a complaint and we'll deal with it.

Resident 6: [sounding irate] Can you say something more than 'make a complaint'...don't keep telling us to phone and make a complaint 'cos it makes no difference.

These tensions, complaints and challenges continue as the meeting progresses, leading to a crisis point, when Resident 6 leaves the room, angrily complaining about the lack of police action. This resident, clearly not a regular attendee, is turned on by the other residents accursed of 'spoiling' the meeting. In doing so, the other residents are seen to corral around PC Joe becoming a united identity against this intruder:

Resident 1: Bit of zero tolerance is what we need. Fine a few $£ 30$ ! It means less money for alcohol.

Resident 6: [stabbing his finger at the police officer as he speaks] This is the easy way out and stop using feeble words. Just admit that you can't do it because there is not enough of you and not enough money. Stop making excuses!

PC Joe: Yes, I heard you. I will report the complaints from this meeting to my superior but if these attacks on the Service continue I will have to throw people out of the meeting. 
Resident 8: [angrily addressing resident 6] Can you be quiet please? You're spoiling our meeting. You're wasting valuable time and we don't meet very often.

At this point, Resident 6 leaves the meeting after this interaction, appearing deflated, still muttering about police inaction.

These extracts demonstrate the residents' escalating level of frustration. PC Joe struggles in his defence of a dispassionate, procedural and bureaucratised NP subjectivity and with his refusal to engage with the residents' contrasting subject position. By attempting to re-establish his own identity within the PACT interactions, not only is PC Joe resisting the residents' construction of the policing subject, but also he is refuting it by positioning himself within a more lenient law and order discourse: 'Some officers have got into trouble for being too heavy handed. My method is far more gentle'.

Confronted by these persistent challenges PC Joe increasingly draws on zerotolerance discourses of policing and law and order to maintain control of the meeting, adopting a more authoritarian subject position that is 'tough on crime': 'If they commit an offence we'll arrest them'. He translates and aligns this softer, NP discourse with the harder crime-focused discourse of policing, melding together the two quite distinct subject positions of 'accountable partner' and 'authoritarian crime fighter'. In this identity move, PC Joe positions himself as the 'authoritarian officer' who, while simultaneously defending a citizen-focused approach, threatens an irate law-abiding citizen (Resident 6) with expulsion from the meeting. While Resident 8 attempts to invoke a collective identity, with the use of the subjective pronoun 'our' in challenging the angry resident, the 'them versus us' distinction and noticeable clash of 
interests continues throughout this set of interactions. This requires increased efforts to promote a sense of shared identity at the meeting.

\section{The promotion of a 'shared identity' by the police and councillors}

A third set of interactions focus on the promotion of a shared, collective identity. In a manoeuvre to encourage a positive disposition towards NP, PC Joe introduces the youth workers and offers a collective identity of public service providers who work in partnership with the community. There are tentative beginnings of a partnership subjectivity, formed through the interactions between PC Joe and the residents, with a scattering of collective personal pronouns used by PC Joe to invite in members to this subject position: 'Are we happy with that?' This subject position is then taken on by meeting members, for example, one resident states: 'more working with us!'). The police in these interactions position themselves as hard-working public servants acting for the good citizens of the community.

A proportion of all PACT meetings are always sets aside for 'good news' stories. In the Aberderi PACT, PCSO Gareth presents a good news story which emphasises what the PCSOs have been doing in the local school: 'We've been working with the lads and teachers... and that's what it's all about, isn't it?' By detailing various activities, PCSO Gareth reconstructs a positive subject position of the PCSO as the stalwart NP officer working with the community. Similarly, the councillors contribute to a reaffirmation of the NP discourse and associated subject position, and partnership governance discourse:

We'll talk to the other councillors about it. We are very fortunate to have these three good officers plodding around the town doing their best and I know they 
take things up - and they are always available and we could thank them. Chwarae teg! ${ }^{3}$ [Cllr Williams].

Where residents resist 'soft policing', skilful identity manoeuvres are required to defuse tension and persuade the resident attendees to accept alternative subject positions. Here the previously silent councillors are positioned as 'accountable partners', working alongside the police to improve quality of life issues. The partners dominate these interactions, with both the police and councillors' contributions promoting discourses of joined-up governance, softer strands of the policing discourse and an empowered public service. They also emphasise the 'we-ness' of the community: 'We are still a community. The community is us. If we want to improve it we have to get involved'. The shared concerns of all present are clear in this appeal to a collective, integrated community discourse and to the 'good neighbours' at the meeting who are seen now to represent the community. Resident 6 does not participate in such practices and consequently is silenced, denied agency by the meeting's regular participants and the police.

\section{DISCUSSION AND CONCLUSIONS}

In this paper we take a close reading of the interactions in a public meeting involving policing professionals, other public service officials and local residents to illustrate the challenges and difficulties of collaborative work within NPG. Identity has become a popular concept within organisational analysis but has been overlooked as a feature of analysis in public sector collaborations, where the focus is more often on organisational efficiencies and technological effectiveness (Dickinson and Sullivan 2014). We theorise the process of identity construction as situated, relational and 
interpersonal, comprising of both individual activity and social constraint. This approach enables us to chart how individuals seek to persuade, defend and legitimate positions in collaborative situations, drawing on a range of competing discourses. Increasingly researchers have called for a focus on the micro-level of collaboration, and in particular 'the situated agency of those charged with making collaboration happen' (Dickinson and Sullivan 2014, 172). Our relational identities framework places power, identity and agency at the heart of analysis of collaboration. As such, it makes three contributions to understanding the challenges of the collaboration project in public service modernisation and the increased demands created for front line public sector employees.

First, taking a relational identities approach (Creed et al. 2010), highlighting the dynamic interplay of discourse, identity and agency in collaborative working, we demonstrate the complex relations and micro-political manoeuvres that underpin collaborative practice. Thus, through focusing on a single meeting and showing collaboration as it happens, we offer an in-depth critical exploration of the lived experience and politics of collaboration in specific contexts. This context presents the tools from which identities are (re)formulated, providing the conditions of possibility for individuals to be warranted voice by speaking from a certain subject position, to gain status or legitimacy, and to influence others. Equally, we demonstrate how, when individuals fail to speak from salient discourses within the meeting, they fail to have a voice. Thus, we contribute to studies concerned with the effectiveness of collaborative working (Hughes 2007; Sullivan et al. 2012; Vangen et al. 2015) by demonstrating the mechanisms of collaborative interactions and the dynamic relationship of discourse, identity and agency in achieving specific collaborative outcomes. 
Our second contribution is to the literature on deliberative democracy. While the focus on effective collaboration has emphasised the need to redress power imbalances in favour of citizens (Arnstein 1969), we draw attention to the challenges and constraints often facing public service participants in such arrangements. NPG has been posited as an emergent response to entrenched, wicked problems (Bryson, Crosby and Bloomberg 2014), yet the literature rarely considers the additional burden this can place on front line staff who are now required to address extra demands, many of which are beyond their remit. While, on the one hand, the paper demonstrates how individuals skilfully negotiate these multiple demands in pursuit of particular outcomes, manoeuvring through false starts, arguments and re-articulations of subject positions, equally, on the other, it also points to the constraints facing front line police officers who must respond to the unpredictable flow of interactions with citizens and handle the various demands made of them, while still maintaining control of the meeting. The demands made by what is often a narrow representation of citizens may neither be possible nor desirable for wider public value (Alford 2016, 680). Thus, focusing on the interactional aspects of collaboration highlights the stressful and often relentless pressures that front line officers can face when working collaboratively. We add therefore to the literature that problematizes the assumed efficiencies gained from collaborative working (Ansell and Gash 2007; Newman and Clarke 2009; Hardy et al. 2005), showing the increased demands, challenges and constraints for front line public sector employees and for the communities they serve.

Our third contribution emphasises the importance of context, linking the micro-political manoeuvres in specific settings to the political arenas in which collaborative forums operate. Accounts of collaboration often emphasise its advantages, in particular its ability to create synergistic, innovative solutions to 
complex social issues (Gilling 2007; Ling 2002; Andrews and Entwistle 2010; Bryson et al. 2014) by empowering citizens (Guarneros-Meza et al. 2009; Dickinson and Sullivan 2014). Taking a context-specific focus, we argue that the wider discursive context has been underappreciated in previous research. Part of this contextual information includes the historical institutional power of the police, which confers an elitist professional identity. PACT meetings were set up unilaterally by the police, with no input from other public service partners or community residents concerning their design or operation. This means that they are often interpreted as 'belonging' to the police rather than the wider collaborative partnership, suggesting a degree of tokenism (Arnstein 1969) rather than citizen empowerment. Within the PACT context certain discourses that emphasise partnership or soft and visible policing compete against more established and entrenched discourses of hard policing and law and order. The police are constrained in the meetings by the existing contextual, historical arrangements which circumscribe identities, actions and collaborative opportunities. Thus, despite the relatively positive portrayal of collaborative arrangements in NPG, we argue that a contextualised approach demonstrates the gap between expected and actual public value. Discourses not only provide the resources for participants to engage in collaborative governance but also help to promote a constrained policing subjectivity, a silenced public service partner, and a marginalised community member.

To conclude, this paper addresses calls for a recasting of collaboration by demonstrating how identities, creatively deployed in interaction and formed in discourse, can achieve particular outcomes. Through a fine-grained analysis of social interactions in a specific, localised context, we lay bare the power struggles and identity manoeuvres involved in collaborative forms of governance, showing how 
agential identities arise in the adoption, resistance, adaptation and manoeuvring between prevailing discourses and subject positions. The article demonstrates that there are limits to participation for all parties involved in collaborative governance, as well as significant identity costs that can be incurred at individual, organisational and societal levels. Collaboration in practice is a dynamic, multifaceted and socially constructed activity that creates a charged and often tense work environment for both the police and other partners, with no guarantee of greater efficiencies and effectiveness of services or indeed enhanced public value for citizens and communities.

\footnotetext{
Notes:

${ }^{1}$ Policing jurisdiction areas in the UK are divided into 43 constabularies.

${ }^{2}$ Bobby is British slang, being an affectionate nickname for a police constable (PC), originating from Robert Peel (Bobby being an abbreviation for Robert in English), the founder of the Metropolitan Police. The need to have more 'bobbies on the beat' has become a popular political discourse in the UK, i.e. for the police to have a greater neighbourhood presence and to be an integral part of community life (beat being slang for a small area under the jurisdiction of an individual officer).
}

3 This is a Welsh expression meaning 'fair play' and is a commonly used idiom in Wales used to promote a feeling of agreement, empathy and inclusiveness 


\section{References}

Agranoff, R., and M. McGuire. 2003. Collaborative Public Management: New

Strategies for Local Governments. Washington, DC: Georgetown University Press.

Al-Amoudi, I., and H. Willmott. 2011. "Where Constructionism and Critical Realism Converge: Interrogating the Domain of Epistemological Relativism." Organization Studies 32 (1): 27-46. doi:10.1177/0170840610394293.

Alford, J. 2002. "Why Do Public-Sector Clients Co-produce?: Toward a Contingency Theory." Administration \& Society 34 (1): 32-56. oi:10.1177/0095399702034001004.

Alford, J. 2016. “Co-Production, Interdependence and Publicness: Extending public service-dominant logic.” Public Management Review 18 (5): 673-691. doi:10.1080/14719037.2015.1111659.

Alvesson, M., K. L. Ashcraft, and R. Thomas. 2008. "Identity Matters: Reflections on the Construction of Identity Scholarship in Organization Studies.” Organization 15 (1): 5-28. doi:10.1177/1350508407084426.

Andrews, R., and T. Entwistle. 2010. "Does Cross-Sectorial Partnership Deliver? An Empirical Exploration of Public Service Effectiveness, Efficiency \& Equity.” Journal of Public Administration Research \& Theory 20 (3): 679-701. doi: https://doi.org/10.1093/jopart/mup045

Ansell, C. and A. Gash. 2007. "Collaborative Governance in Theory and Practice". Journal of Public Administration and Theory 18 (4): 543-571. doi: https://doi.org/10.1093/jopart/mum032. 
Arnstein, S. R. 1969. “A Ladder of Citizen Participation”. Journal of the American Planning Association 35 (4): 216-224. doi:

http://dx.doi.org/10.1080/01944366908977225.

Bang, H. 2002. "Opening up the political system via cultural governance”. Paper from the Institute for Political Science, University of Copenhagen, Denmark.

Barnes, M., J. Newman, and H. Sullivan. 2007. Power, Participation and Political Renewal: Case Studies in Public Participation. Bristol: Policy Press.

Baxter, J. 2011. Public Sector Professional Identities: A Review of the Literature. Milton Keynes: The Open University.

Beech, N., and C. Huxham. 2003. "Cycles of Identity Formation in Interorganizational Collaborations.” International Studies of Management and Organization 33 (2): 28-52. doi:10.1080/00208825.2003.11043686.

Bevir, M., and F. Trentmann. 2007. Governance, Consumers and Citizens: Agency and Resistance in Contemporary Politics. London: Palgrave Macmillan.

Bovaird, T. 2007. "Beyond Engagement and Participation: User and Community Coproduction of Public Services”. Public Administration Review 67 (5): 846-860. doi: 10.1111/j.1540-6210.2007.00773.x.

Brent, J. 2004. “The Desire for Community: Illusion, Confusion and Paradox.” Community Development Journal 39 (3): 213-223. doi: 10.1093/cdj/bsh017.

Brown, A.D. 2015. "Identities and Identity Work in Organizations." International Journal of Management Reviews 17 (1): 20-40. doi: 10.1111/ijmr.12035. 
Brunger, M. 2011. "Governance, Accountability and Neighbourhood Policing in Northern Ireland: Analysing the Role of Public Meetings." Crime, Law and Social Change 55 (2-3): 105-120. doi:10.1007/s10611-011-9273-x.

Bryson, J.M., C. Crosby and L. Bloomberg. 2014. "Public Value Governance: Moving Beyond Traditional Public Administration and the New Public Management". Public Administration Review 74 (4): 445-456. doi: 10.1111/puar.12238.

Bullock, K. 2010. “Generating and Using Community Intelligence: The Case of Neighbourhood Policing." International Journal of Police Science \& Management 12 (1): 1-11. doi:10.1350/ijps.2010.12.1.153.

Clarke, J., J. Newman, N. Smith, L. E. Vidler, and L. Westmarland. 2007. Creating Citizen-Consumers? Changing Publics and Changing Public Services. London: SAGE.

Crawford, A. 2007. "Crime Prevention and Community Safety.” In The Oxford Handbook of Criminology, edited by Maguire, M., R. Morgan \& R. Reiner. Oxford: Oxford University Press.

Creed, W. D., R. DeJordy, and J. Lok. 2010. “Being the Change: Resolving Institutional Contradiction through Identity Work.” Academy of Management Journal 53 (6): 1336-1364. doi:10.5465/AMJ.2010.57318357.

Davies, B., and R. Harré. 1990. "Positioning: The Discursive Production of Selves." Journal for the Theory of Social Behaviour 20 (1): 43-63.

doi:10.1111/j.1468-5914.1990.tb00174.x. 
Davies, A., and R. Thomas. 2008. "Dixon of Dock Green Got Shot! Policing Identity Work and Organizational Change.” Public Administration 86 (3): 627-642. doi:10.1111/j.1467-9299.2008.00744.x

Dickinson, H. 2016. "From New Public Management to New Public Governance: The implications for a "new public service'”. In The Three Sector Solution: Delivering public policy in collaboration with not-for-profits and business, edited by J. Butcher and D. Gilchrist. Canberra, Australia: ANU Press, The Australian National University.

Dickinson, H., and H. Sullivan. 2014. "Towards a General Theory of Collaborative Performance: The Importance of Efficacy and Agency.” Public Administration 92 (1): 161-177. doi:10.1111/padm.12048.

du Gay, P. 1996. Consumption and Identity at Work. London: SAGE.

Flanagan, R. 2008. The Review of Policing. London: Home Office.

Foucault, M. 1972. The Archaeology of Knowledge. New York: Harper and Row.

Foucault, M. 1990. The History of Sexuality Volume 1: An Introduction. London: Penguin Books Ltd.

Gasper, R., and A. Davies. 2016. "Revisiting the Potential of Community Empowerment within UK Neighbourhood Policing Meetings.” Policing and Society. Advance online publication. doi:10.1080/10439463.2016.1161040.

Giddens, A. 1976. New Rules of Sociological Method. London: Hutchinson. 
Giddens, A. 1991. Modernity and Self-Identity: Self and Society in the Late Modern Age. Stanford: Stanford University Press.

Gilling, D. 2007. Crime Reduction and Community Safety: Labour and the Politics of Local Crime Control. Cullompton: Willan Publishing.

Guarneros-Meza, V., J. Downe, T. Entwistle, and S. Martin. 2009. Learning to Improve: An Independent Assessment of the Welsh Assembly Government's Policy for Local Government, First Interim Report July 2009. Cardiff: Centre for Local \& Regional Government Research, Cardiff Business School.

Halford, S. and P. Leonard. 2006. "Place, Space and Time: Contextualizing Workplace Subjectivities.” Organization Studies 27 (5): 657-676. doi:10.1177/0170840605059453.

Hall, S. 2001. "Foucault: power, knowledge and discourse". In Discourse, Theory and Practice: A Reader, edited by M. Wetherell, S. Taylor and S. Yates. London: SAGE/The Open University, 72-81.

Hardy, C., T. B. Lawrence, and D. Grant. 2005. "Discourse and Collaboration: The Role of Conversations and Collective Identity." Academy of Management Review 30 (1): 58-77. doi: http://www.jstor.org/stable/20159095.

Herbert, S. 2006. Citizens, COPs and Power: Recognising the Limits of Community. Chicago: The University of Chicago Press.

Hodgson, L. 2004. "Manufactured Civil Society: Counting the Cost." Critical Social Policy 24 (2): 139-164. doi:10.1177/0261018304041948. 
Hook, D. 2001. "Discourse, knowledge, materiality, history: Foucault and discourse analysis". Theory and Psychology, 11 (4): 521-547.

Huey, L., and M. Quirouette. 2010. “Folks Should Have Access ... How You Do It Is the Difficult Thing': Exploring the Importance of Leadership to Maintaining Community Policing Programmes for the Homeless." Policing and Society: An International Journal of Research and Policy 20 (2): 172-186. doi:10.1080/10439461003668484.

Hughes, G. 2007. Crime and Community. London: Palgrave.

Huxham, C. 2000. "The Challenge of Collaborative Governance.” Public Management 2 (3): 337-357. doi: 10.1080/14719030000000021.

Huxham, C. 2003. "Theorizing collaboration practice." Public Management Review 5 (3): 401-423. doi:10.1080/1471903032000146964.

Huxham, C. and S. Vangen 2004. "Doing Things Collaboratively: Realizing the Advantage or Succumbing to Inertia?” Organizational Dynamics 33 (2): 190-201. doi: https://doi.org/10.1016/j.orgdyn.2004.01.006.

Huxham, C. and S. Vangen 2005. Managing to Collaborate: The Theory \& Practice of Collaborative Advantage. London: Routledge

Innes, M. 2005. "Why 'Soft' Policing is Hard: On the Curious Development of Reassurance Policing, How it Became Neighbourhood Policing and What This Signifies about the Politics of Police Reform.” Journal of Community and Applied Social Psychology 15 (3): 156-169. doi: 10.1002/casp.818. 
Jones, T., and C. Ormston. 2014. "Localism and Accountability in a Post-

Collaborative Era: Where Does It Leave the Community Right to Challenge." Local

Government Studies 40 (1): 141-161. doi:10.1080/03003930.2013.801834.

Klijn, E.H. and Koppenjan, J. (2016) Governance Networks in the Public Sector.

Routledge: Abingdon, Oxon.

Komporozos-Athanasiou, A., and M. Thompson. 2015. "The Role of Emotion in Enabling and Conditioning Public Deliberation Outcomes: A Sociological Investigation.” Public Administration 93 (4): 1138-1151.

doi:10.1111/padm.12188.

Liederbach, J., E. J. Fritsch, D. L. Carter, and A. Bannister. 2007. "Exploring the Limits of Collaboration in Community Policing: A Direct Comparison of Police and Citizen Views.” Policing: An International Journal of Police Strategies and Management 31 (2): 271-91. doi:10.1108/13639510810878721.

Ling, T. 2002. "Delivering Joined-Up Government in the UK: Dimensions, Issues and Problems." Public Administration 80 (4): 615-642. doi:10.1111/1467-9299.00321.

Maguire, S., and C. Hardy. 2005. "Identity and Collaborative Strategy in the Canadian HIV/AIDS Treatment Domain.” Strategic Organization, 3 (1): 11-45. doi:10.1177/1476127005050112.

Martin, G.P. 2012. "Public Deliberation in Action: Emotion, Inclusion and Exclusion in Participatory Decision-Making.” Critical Social Policy 32 (2): 163-183. doi:10.1177/0261018311420276. 
Martin, G.P. 2011. “The Third Sector, User Involvement and Public Service Reform:

A Case Study in the Co-Governance of Health Service Provision." Public

Administration 89 (3): 909-932. doi:10.1111/j.1467-9299.2011.01910.x.

McMurray R., A. Pullen, and C. Rhodes. 2011. "Ethical Subjectivity and Politics in Organizations: A Case of Health Care Tendering.” Organization 18 (4): 541-61.

Meyer, R., and G. Hammerschmid. 2006. "Public Management Reform: An Identity Project." Public Policy and Administration 21 (1): 99-115.

doi:10.1177/095207670602100107.

Newburn, T., and T. Jones. 2007. "Symbolizing Crime Control: Reflections on Zero Tolerance." Theoretical Criminology 11 (2): 221-243.

doi:10.1177/1362480607075849.

Newburn, T., and R. Reiner. 2007. "Policing and the Police." in The Oxford

Handbook of Criminology, edited by Maguire, M., R. Morgan, and R. Reiner. Oxford: Oxford University Press.

Newman, J., M. Barnes, H. Sullivan, and A. Knops 2004. "Public Participation and Collaborative Governance”. Journal of Social Policy 33 (2): 203-223. doi: https://doi.org/10.1017/S0047279403007499.

Newman, J. and J. Clarke. 2009. Publics, Politics and Power-Remaking the Public in Public Services. London: SAGE.

Osborne, S.P. 2006. “Editorial: The New Public Governance?”. Public Management Review 8 (3): 377-387. doi: http://dx.doi.org/10.1080/14719030600853022. 
Poocharoen, O and B. Ting. 2015. "Collaboration, Co-Production, Networks". Public Management Review 17 (4): 587-614. doi:

http://dx.doi.org/10.1080/14719037.2013.866479.

Rhodes, R.A.W. 2007. “Understanding Governance: Ten Years On”. Organization Studies 28 (8): 1243-1264.

Sagar, T., and D. Jones. 2013. "Priorities for the Minority? Street-Based Sex Work and Partnerships \& Communities Together (PACT)." Criminology and Criminal Justice 13 (4): 431- 445. doi:10.1177/1748895812454749.

Skelcher, C. and H. Sullivan. 2008. "Theory-Driven Approaches to Analysing Collaborative Performance.” Public Management Review 10 (6): 751-771. doi:10.1080/14719030802423103.

Skogan, W. 2006. “Asymmetry in the Impact of Encounters with the Police.” Policing and Society. 16 (2): 99-126. doi:http://dx.doi.org/10.1080/10439460600662098.

Somerville, P. 2009. "Understanding Community Policing.” Policing: An International Journal of Police Strategies \& Management 32 (2): 261-277. doi:10.1108/13639510910958172.

Sullivan, H., P. Williams, and S. Jeffares. 2012. "Leadership for Collaboration." Public Management Review 14 (1): 41-66. doi:10.1080/14719037.2011.589617. Terpestra, J. 2009. “Citizen Involvement in Local Security Networks.” Security Journal 22 (2):156-69. doi:10.1057/palgrave.sj.8350079. 
Thomas, R. 2009. "Critical Management Studies on Identity: Mapping the Terrain.” In The Handbook of Critical Management Studies. Edited by Alvesson, M., H.

Willmott, and T. Bridgman. Oxford: Oxford University Press.

Thomas, R., and A. Davies, A. 2005. “Theorising the Micro-Politics of Resistance:

Discourses of Change and Professional Identities in the UK Public Services.”

Organization Studies 26 (5): 683-706. doi:10.1177/0170840605051821.

Tomlinson, F. 2005. "Idealistic and Pragmatic Versions of the Discourse of

Partnership.” Organization Studies 26 (8): 1169-1188.

doi:http://dx.doi.org/10.1177\%2F0170840605055338.

Utting, D. 2009. Contemporary social evil. Bristol: Policy Press (published for the Joseph Rowntree Foundation).

Vangen, S., J. P. Hayes, and C. Cornforth. 2015. “Governing Cross-Sector, InterOrganizational Collaborations.” Public Management Review 17 (9): 1237-1260. doi:10.1080/14719037.2014.903658.

Watson, T. J. 2008. "Managing Identity: Identity Work, Personal Predicaments and Structural Circumstances.” Organization 15 (1): 121-143.

doi:10.1177/1350508407084488.

Weedon, C. 1997. Feminist practice and poststructuralist theory. Oxford: John Wiley $\&$ Sons.

Ybema, S., R. Thomas, and C. Hardy. 2016. "Organisational Change and Resistance: An Identity Perspective.” In The SAGE Handbook of Resistance. Edited by Courpasson, D. and S. Vallas. London: SAGE. 
Young, J. 2003. "Searching for a New Criminology of Everyday Life.” British Journal of Criminology 43 (1): 228-43. doi:https://doi.org/10.1093/bjc/43.1.228. 
Table 1: Extract from meeting showing data analysis

\begin{tabular}{|c|c|c|c|c|}
\hline & Text from meeting & Analysis of interactions & $\begin{array}{l}\text { Discourse \& } \\
\text { discursive strands }\end{array}$ & Subject position \\
\hline PC Joe: & $\begin{array}{l}\text { So, the priorities that we set last month } \\
\text { were, um, youth annoyance in Aberderi } \\
\text { park, especially around The Community } \\
\text { Hut; youth annoyance and damage to cars } \\
\text { in Manor Street and parking along } \\
\text { Treherbert Street. We've now been running } \\
\text { these meetings for the past } 8 \text { or } 9 \text { months } \\
\text { and I'd like to thank you all for your help } \\
\text { and regular attendance. You are the eyes } \\
\text { and ears of the community. So, let's kick } \\
\text { off with the problems we're been having } \\
\text { with youngsters around the Community } \\
\text { Hut. We've had officers patrolling the area } \\
\text { but no offences have been reported }\end{array}$ & $\begin{array}{l}\text { Joe positioned himself - supported } \\
\text { by others - as leader of the meeting, } \\
\text { running the show, with 'business as } \\
\text { usual'. } \\
\text { Meeting members are positioned by } \\
\text { Joe in a subordinate position, } \\
\text { assisting but also supporting NP } \\
\text { policing } \\
\text { Community constructed as stratified: } \\
\text { the helpful meeting regulars as the } \\
\text { 'eyes and ears' for the police and the } \\
\text { 'problem youth' }\end{array}$ & $\begin{array}{l}\text { Soft and visible } \\
\text { policing } \\
\text { Cohesive community } \\
\text { Broken community } \\
\text { Community partner } \\
\text { governance }\end{array}$ & Accountable partner \\
\hline R. 1: & $\begin{array}{l}\text { Could you issue some warning about } \\
\text { carrying weapons and kids on quad bikes? }\end{array}$ & $\begin{array}{l}\text { Joe's subjectivity as NP officer is } \\
\text { challenged by resident demanding a } \\
\text { more interventionist approach }\end{array}$ & Zero tolerance & Law abiding citizen \\
\hline PC Joe: & $\begin{array}{l}\text { Well, there's a fine line on how to play it. } \\
\text { Actually, there's a lot of good kids that use } \\
\text { the park. We don't want to adopt a heavy- } \\
\text { handed approach and we need to find a } \\
\text { balance in dealing with this problem. The } \\
\text { other priority was the reports of youth } \\
\text { annoyance from last month which had been } \\
\text { damage to cars in Manor Street. Can I ask if }\end{array}$ & $\begin{array}{l}\text { Joe dismissed the resident's } \\
\text { suggestion, labelling it as 'heavy } \\
\text { handed'. Reasserting his NP subject } \\
\text { position, Joe continued to run } \\
\text { through priorities set in the previous } \\
\text { meeting. He also drew on the } \\
\text { residents to confirm his subjectivity } \\
\text { and to reassert his leadership }\end{array}$ & Soft policing & Accountable partner \\
\hline
\end{tabular}




\begin{tabular}{|l|l|l|l|l|}
\hline & there has been an improvement now? & position. & & \\
\hline R. 2: & Much better thanks & $\begin{array}{l}\text { Resident reconfirmed Joe's subject } \\
\text { position }\end{array}$ & $\begin{array}{l}\text { Soft policing } \\
\text { Cohesive community }\end{array}$ & Good neighbour \\
\hline
\end{tabular}


Table 2: Discourses and associated subject positions

\begin{tabular}{|c|c|c|}
\hline Discourse & Description & Subject position(s) \\
\hline $\begin{array}{l}\text { 1. Professional-policing } \\
\text { a) Hard/Force [separate, crime } \\
\text { focused, response] } \\
\text { b) Soft/Service [integrated, problem } \\
\text { and community oriented, partnership] } \\
\text { c) Visible/Reassurance [present, } \\
\text { embodied, in community] }\end{array}$ & $\begin{array}{l}\text { Discourse of policing comprising of overlapping, sometimes competing (and } \\
\text { contested) discursive strands. }\end{array}$ & $\begin{array}{l}\text { a) Authoritarian crime fighter } \\
\text { b) Accountable partner } \\
\text { c) 'Bobby on the beat' }\end{array}$ \\
\hline $\begin{array}{l}\text { 2. Community } \\
\text { a) Cohesive, integrated and collective } \\
\text { b) Broken, fragmented and } \\
\text { individualised }\end{array}$ & $\begin{array}{l}\text { Discourse of community presents a stratified collective identity of the cohesive } \\
\text { community, often pitched against an Other of a broken, fragmented and } \\
\text { individualised society. }\end{array}$ & $\begin{array}{l}\text { a) Good neighbour } \\
\text { b) Anti-social individual/group }\end{array}$ \\
\hline $\begin{array}{l}\text { 3. Law and Order } \\
\text { a) Zero tolerance } \\
\text { b) Lenience }\end{array}$ & $\begin{array}{l}\text { Discourse of law and order with two strands. One emphasising: broader } \\
\text { definition of criminal behaviour; quick, harsh responses; a clear delineation } \\
\text { between law abiding citizens and criminal/ anti-social individual/group. The } \\
\text { other emphasising tolerance and professional discretion, with greater blurring } \\
\text { over constitution of criminal versus the vulnerable/ disadvantaged. }\end{array}$ & $\begin{array}{l}\text { a) Upright and law abiding / anti-social } \\
\text { individuals / police-as-agent-of-the- } \\
\text { state } \\
\text { b) Tolerant liberal / socially } \\
\text { disadvantaged, vulnerable, and } \\
\text { marginalised / police-as-social-worker }\end{array}$ \\
\hline $\begin{array}{l}\text { 4. Partnership } \\
\text { a) Community working in } \\
\text { partnership with police }\end{array}$ & $\begin{array}{l}\text { Partnership discourse emphasising two strands: a collective we of police and } \\
\text { community, working together generating solutions; empowered community; } \\
\text { and in contrast, partnership of public service professionals working together to }\end{array}$ & $\begin{array}{l}\text { a) Collective identity of community } \\
\text { (PACT members) and police. }\end{array}$ \\
\hline
\end{tabular}


set agendas and determine service for community.

b) Public service partners (including police) working together (partner generated solutions)

c) 'Us and them' discourses between public service partners and between the police and the community

\section{Public Service}

a) Constrained and contained public service; limited resources

b) Empowered and joined up government
Partnership discourses may also be pitched against an 'us and them' governance discourse in which public agents work 'in silos', and with conflict between the police and the community.

Discourse setting out the role of public services and its servants meeting society's needs. Two strands, not necessarily oppositional: a constrained and circumscribed service, with limited scope and powers and constrained by lack of resources; and a 'smarter', empowered provision of public service through more entrepreneurial and joined-up solutions to societal problems. b) Issue-specific collective identity of public service professionals

c) Separate and individual identities of the police; other public service partners; and different community members

a) Disempowered and resource constrained public servant

b) Empowered and innovative problem-solver 
